Teosofia: Indonesian Journal of Islamic Mysticism, Vol. 9, No. 2, 2020, pp. 259-279

e-ISSN: 2540-8186; p-ISSN: 2302-8017

DOI: $10.21580 /$ tos.v9i2.6773

\title{
CRITICAL ANALYSIS ON TASAWWUF SCHOOLS
}

\author{
Mokhamad Rohma Rozikin \\ Universitas Brawijaya Malang \\ rohma.rozikin@ub.ac.id
}

Article History: Received: 23 June 2020, Accepted: 29 October 2020, Published: 2 November 2020

\begin{abstract}
:
As one of disciplines, Sufism has undergone the stages of scientific development. It is difficult to reach an agreement related to the classification of Sufism schools from the first time it appeared until today. However, by taking the characteristics of each thought into account, Sufism can be classified into several schools, namely Rajā 'wa khauf Sufism, Mahabbah Sufism, Happy Sufism, Al-Hallāj Sufism, Al-Gazzā ז̀ Sufism, Philosophical Sufism, and Ibn Taimiyyah Sufism. Sufism that grew in the early days, in the first and second centuries of Hegira, such as Mahabbah and Rajā' wa khauf Sufism, was in general undisputed because it was still far from the influence of foreign elements and had strong attachments to Al-Qur'an and Sunah. Sufism in the third and fourth centuries of Hijra, although from the scientific side is more established, systematic, and structured, the symptoms of conflict with Fiqh began to grow which reached its peak in the time of Al-Halläj. Sufism in the fifth century, at the time of AlGazzā $\bar{l}$, was the most beautiful period in the history of Sufism because Sufism and Fiqh could be integrated. Sufism in the next period began to had another conflict because of the influence of philosophy until the time of Ibn Taimiyyah who wanted to return Sufism to its origin. This paper conducted a literature review on the history of Sufism to capture the schools that have emerged since its inception. In the final section, a critical analysis of the Sufism schools was carried out and it was closed with a few ideas on how to eclectically adapt the results of this critical analysis for the Islamic Education learning.
\end{abstract}

Keywords: Sufism, schools, critical analysis, Sufi, philosophy

\section{A. Introduction}

حasawwuf (التََّصَوُْف) in English is often translated as sufism or mysticism¹. In terms of the origin of the term, there has always been no agreement. Al-Syibli admitted that the origin of the term Sufism was indeed disputed for a long time $^{2}$. Therefore, there is no definite information to choose which one is believed to be the most correct. There are those who argue that the word Sufism comes from safä'

1 Muhammad Rawas Qalaji and Hamid Sadiq Quneibi, Mu'jamu Lughoti Al-Fuqoha', 2nd ed. (Beirut: Dar al-Nafaes, 1988), 133.

2 Abdul Ḥalīm Maḥmūd, Qạ̣iyyatu Al-Taṣawwuf Al-Munqiż Min Al-Ḍalāl (Beirut: Dār al-Ma'ārif, n.d.), 29. 
(الصَّفَاءُ) to refer to the cleanness of the hearts of the Sufis and the cleanness of their muamalah to Allah. Some argue that it is from șaff(الصيَّفُ (الن ) because the Sufi is always at

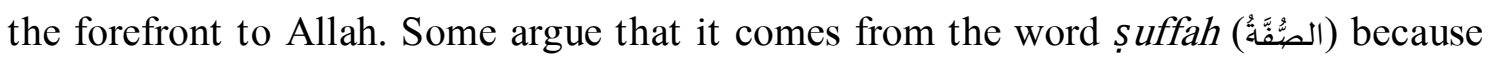
they imitated the condition of ahlus șuffah at the time of the Prophet 繗. There are also those who argue that it originated from the word $s \bar{u} f($ الصُوْوفُو because the Sufis liked to wear fur as a symbol of modesty ${ }^{3}$. Samīh 'Ațif al-Zain even cites the possibility that it comes from the word sophism, because the Sufis are fond of words of sophistication and wisdom ${ }^{4}$.

That's just debating the origin of the words Sufism. In terms of meaning, the debate is even greater. There are many differences of opinion regarding the meaning of Sufism in terms. Some scholars said there are 20 ikhtilaf. Al-Qusyairī in al-Risālah alQusyairiyyah mentioned more than 50 different definitions. Nickolson mentioned 78 definitions. Al-Sarrāj mentioned 100 definitions in the book al-Luma'. Al-Suhrawardī in 'Awārifu al-Ma'ârif quoted from some scholars that the definition is more than 1000. Al-Hāmidī in the book al-Insān wa al-Islam even mentioned nearly 2000 definitions ${ }^{5}$.

Regardless the debate of various kinds of opinions about the definition of Sufism and by taking a simple interpretation based on what it appears, Sufism can be defined as the science of cleansing the soul, or the science of morals, or the science of selfcleansing in the way to Allah. Maybe we also understand Sufism as ascetic life as Hamka's opinion ${ }^{6}$. In the book Mu'jam Lugati al-Fuqahā', tașawwuf is defined as follows ${ }^{7}$.

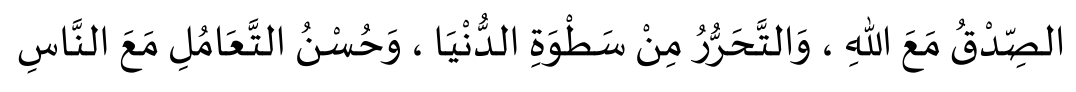

\section{B. A Brief History of the Sufism Development}

If Sufism is defined as the science of cleansing the soul and moral education to walk towards Allah which emphasizes spiritual life, then the history of its development in the Islamic world can be classified into several stages, namely Sufism during the time of the Prophet and his companions, Sufism in the $1^{\text {st }} \& 2^{\text {nd }}$ century of the Hegira, Sufism in the $3^{\text {rd }} \& 4^{\text {th }}$ century, Sufism in 5th century, Sufism in $6^{\text {th }} \&$ $7^{\text {th }}$ century, and Sufism in $8^{\text {th }}$ century of the Hegira until our day.

3 Iṇsān Ilāhī Ẓahīr Al-Bākistānī, Al-Taṣawwuf Al-Mansya’ Wa Al-Maṣādir (Lahore: Idāratu Turjumān al-Sunnah, 1986), 20-21.

4 Samīḥ 'āṭif Al-Zain, Al-Șūfiyyah Fi Naẓari Al-Islām Dirāsah Wa Taḥlil (Beirut: Dār Al-Kitāb AlLubnānī, 1985), 17.

5 Al-Bākistānī, Al-Tașawwuf Al-Mansya’ Wa Al-Mașā dir, 36-37.

6 Hamka, Perkembangan \& Pemurnian Tasawwuf Dari Masa Nabi Muhammad Hingga Sufi-Sufi Besar, 2nd ed. (Jakarta: Putra Abdi Bangsa, 2017), 85.

7 Qalaji and Quneibi, Mu'jamu Lughoti Al-Fuqoha', 133. 
As for the time of Rasulullah his own life style did show a way of human life that really emphasized spiritual life and was far from material life. Prophet very simple. Her room was simple. There were only a mat, a skin bag of water and a few tools. Umar ibn Al-Khatțāab who had visited him in his room shed tears seeing his modesty. How could he did not cry seeing the messenger of Allah who was given the keys to eastern and western powers, who was able to thrill Rome and Persia, turned out to choose a life that was far from being luxurious. In fact, when Umar proposed to Rasulullah to make his followers rich, he gently rebuked Umar that the luxury of life is only a temporary pleasure for unbelievers. As for those who are loved by Allah, the true pleasure that should be pursued, namely the pleasure after death. Rasulullah was also offered whether he wanted to be a rich prophet like Prophet Solomon or a poor prophet like the prophet Ayyub. It turned out that his answer was to want to be hungry for a day and full for a day. Therefore, when he is full, he can be grateful and when he is hungry, he can be patient ${ }^{8}$. This kind of life is also continued by his Companions (Șahābah). It is a well-known story that Umar bin al-Khatțāb made a speech while in his clothes, there were 12 patches. There is also the story of Abu Bakr who died by handing over all the assets he got from his salary to Baitul Mal. There is also the story of Ali who had to work to collect water from a well of a Jew to get a date for every bucket. There is also a story of Abū Zarr who consistently called for a simple life and rebuked some people who started to become complacent and excessive in luxury. All of this shows how the legacy of the spiritual life or Sufism in the Companions that they got from the Prophet

\section{The First and Second Century}

When the $1^{\text {st }}$ and $2^{\text {nd }}$ century of Hegira came, spiritual life continued. The emergence of spiritual life at that time was not due to external influences, but grew naturally itself as the influence of the Al-Qur'an, Hadith, imitating the Sahabat's actions and the response to the environmental luxury. However, the spiritual life at that time had not become a systematic science. It had just grown as a science that was practiced, discussed and studied sporadically, not to form an orderly and systematic structure of knowledge yet ${ }^{9}$.

Spiritual life, at this time, never collided with Islamic jurisprudence (fiqh), because the source was still pure from the Qur'an, the hadith of the Prophet and the examples of the Companions. In fact, the jurisprudence experts and mujtahid at that time were also experts in spiritual science. Thus, their zuhud life was always accompanied by a strong attachment to the sharia and fiqh. Malik was known to

8 Hamka, Perkembangan \& Pemurnian Tasawwuf Dari Masa Nabi Muhammad Hingga Sufi-Sufi Besar, 75-76.

9 Hamka, 85.

Teosofia: Indonesian Journal of Islamic Mysticism, Vol. 9, No. 2, 2020 
always keep ablution. Before teaching hadith, he always performed ablution and kneeled respectfully beside the Prophet's grave Ahmad's house, in the middle of the night, Ahmad got up carefully not to wake his teacher; al-Shafi'i'. However, it turned out that al-Shafi'ì had already woken up to pray midnight and dhikr all night long until dawn. Ahmad's daughter was awakened to see it by herself how his teacher's worship was. When Ahmad was asked the meaning of zuhud, he answered with a very beautiful answer from Sufis's point of view. He said that there were three kinds of zuhud. First, leaving the haram. That is the zuhud of common people. Second; leaving unnecessary. That is the zuhud of a special person/khawāṣ. Third: leaving everything that hinders the remembrance of Allah. That is the zuhud of 'arifin ${ }^{10}$.

However, at this time, the term Sufi is still unknown. The terms for people who study spiritual life at this time are nussāk, zuhhād, 'ubbād, fuqarā' and bakkā $\overline{\imath n}^{11}$. However, according to al-Qusyairi, after the terms zuhhād and 'ubbād appeared, then bid'ah appeared, then the term tasawwuf appeared and it happened before the 2nd century. ${ }^{12}$ Al-Gumārī in the book al-Intiṣār li Tarīqi al-Ṣūfiyyah al-Akhyār quotes Ḥājī Khalīfah in Kasyfu al-Zunūn to more specifically mention the initial year of appearance. It was said that the person who was first dubbed a Sufi was Abū Hāsyim al-Ṣufī who died in $150 \mathrm{H}^{13}$

During this period, a number of figures who were prominent in a spiritual life appeared. Among them were Hasan al-Bașrī, Fuḍail bin 'Iyāẹ, Sufyān al-Ś̉aurī, Ibn alSammāk, Rabī'ah al-'Adawiyyah, Malik bin Anas, Ma'rūf al-Karkhī, Ḥāris al-Muhāsibī, Sufyān al-Ṣaurī (97-161 AH), al-Rabī 'bin Khaișam (d. Before 65 AH), Jābir bin Hayyān, Kulaib, Manșūr bin' Ammār, 'Abduk, Malik bin Dīnār (d. 181 H), al-Fạ̣l alRaqqāsȳ̄ (d. 128 H), Rabāḥ bin 'Amr, Șāliḥ bin Bisyr Al-Murrī (d. 172 H), Abdul Wahid bin Zaid (d. $177 \mathrm{H}$ ), Ibrāhīm bin Adham (d. $161 \mathrm{H})$, and Syaqīq al-Balkhī (d. 194). There were also a number of female figures such as Mu'āżah al-'Adawiyyah, Mājidah Al-Qurasyiyyah, 'Ā'isyah bint Ja' far Al-Ṣādiq, Fāṭimah al-Naisābūriyyah, Rabī'ah bint Ismā'īl, Umm Harām, 'Amrah the Habīb's wife, Amatul Jalīlī, 'Abidah bint Abū Kilāb, 'Ufairah al-'Abidah, Sya'rānah, Amīnah al-Ramliyyah, Manfūsah bint Zaid, Nafissah bint Hasan bin Zaid bin Ali bin Abū Țālib. Khawarij and Shi'a groups were also known with the zuhud life. However, they still wanted power. They were different from those who purely want an even spiritual life.

10 Hamka, 111-12.

11 Hamka, 84-85, 87.

12 Abdul Karim bin Hawāzin bin Abdul Malik Al-Qusyairi, Al-Risālah Al-Qusyairiyyah (Tahqīq Abdul Halìm Mạ̣mūd Dan Mạ̣mūd Al-Syan̄f), vol. 11 (Cairo: Dār Al-Ma'ārif, 1989), 34.

13 Al-Zamzami bin muhammad bin Al-Shidiq Al-Gumārī, Al-Intișār Li Ṭañqi Al-Ṣūfiyyah Al-Akhyār, D (Cairo: Dar al-Marjan al-Thaba'ah, 1979), 18. 


\section{The Third and Fourth Century}

Once the $3^{\text {rd }}$ and $4^{\text {th }}$ centuries came, Sufism began to form a structured and ordered science. At that time, the topic of the discussion of Sufism can be divided into three, namely: psychology, morals and magic. The subtlety of taste highlighted in the $1^{\text {st }}$ and $2^{\text {nd }}$ centuries sharpened the quality of the discussion of those three disciplines. The existence of discussion in those three fields was a form of development because previously the discussion of Sufism was prominent in the field of morals only, so that Sufism is also sometimes called the science of morals. However, Sufism is deeper than the science of morals/ethics because the responsibility of ethics tends to be for humans with the meaning of having good characters for not getting a bad stereotype from the society, while Sufism's responsibility is directly to Allah ${ }^{14}$.

The human soul at that time was deeply studied. All the ascensions of the soul

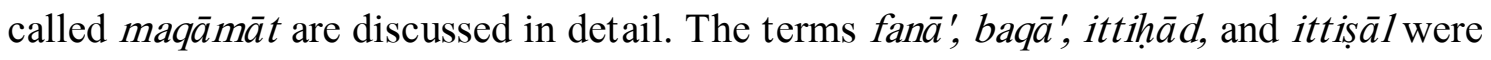
also discussed. At that time, the book al-Ta'arruf li Mażhabi Ahli al-Tașawwuf by alKalābāżī was born (d. 380 H). The book Qūtu al-Quh̄ b by Abū Ṭālib Al-Makkī (d. 386 $\mathrm{AH}$ ) was also born. In the $3^{\text {rd }}$ and $4^{\text {th }}$ century $\mathrm{H}$, the love relationship with the God was deepened. That topic was then elaborated and detailed by the following generations (the $5^{\text {th }}$ century onwards), so that the books such as al-Mahjū by al-Hujwirī (d. 456 H), al-Risālah by al-Qusyairī (d. $465 \mathrm{H}$ ), and Ihyā' 'Uhümiddin by al-Gazzālī (d. $505 \mathrm{H}$ ) were born. In terms of spread range, if in the $2^{\text {nd }}$ century AH, Sufism was only famous in Kufa and Bașrah, then at the beginning of the $3^{\text {rd }}$ century $\mathrm{H}$ it began to spread and be famous to various cities; to Baghdad, Persia, Egypt, Syria, and the Arabian Peninsula.

In Baghdād, the name al-Sañ al-Saqatī (d. 253 AH) was well known. From him, the terms haqiqah, maqūmāt, and ahwāl were emerged. There is also Abu Hamzah Muhammad bin Ibrāhīm al-Șūfī (d. 269 H). From him came the terms 'isyq, żikr, jam'ul himmah, and qurb. There is also Ma'rūf al-Karkhī (d. 200/201 H). He taught drunkenness because of longing and love for Allah. There is also Abū Sulaimān AlDārānī (d. $215 \mathrm{AH})$. He taught that love must be reciprocated, not one-sided. There is also Hạaris̀ al-Muhāsibī (d. 243 AH). Al-Qusyairī said, he was one of the 5 leading figures of Sufism, namely Hāris̀ al-Muhāsibī, Junaid, Ruaim, Ibn Ațā' and Umar bin Uṡmān al-Makkī. He taught; Whoever cleanses himself from murāqabah and is sincere, he will be decorated with mujāhadah and $i t t i b \bar{a}{ }^{\prime}$ sunnah. Another figure who appeared was named al-Junaid al-Bagdādī (d. 297/298 H). He was known to be very strict in carrying out the Sharia. His prayers were up to 400 cycles (raka'ah).

In Egypt did arise Żū al-Nūn al-Mișrī (d. 245 AH). He was considered the pinnacle of Sufi in the $3^{\text {rd }}$ century $\mathrm{H}$. The essence of his teachings was to close all doors to the splendor of the world, follow the Qur'an and the Sunnah, and always

14 Hamka, Perkembangan \& Pemurnian Tasawwuf Dari Masa Nabi Muhammad Hingga Sufi-Sufi Besar, 115-16. 
worry about being turned away from the way because of indulging lust. There are two kinds of repentance, he said; repentance from sins and repentance from negligence. Repentance from sins is the repentance of the common people. Repentance from negligence is the repentance of a special person (khawās). There are three kinds of ma'rifat according to him. Ma'rifat of ordinary believers (by ikhbar/information), ma'rifa of mutakallimin and philosophers (by logic), and ma'rifa of waliyullah who knows Allah by feeling and experience. The last one is the highest ma'rifa because ma'rifa of mutakallimin and ordinary believers only knows, while waliyullah ma'rifa directly feels the pleasure. Therefore, it can be stated that this Ż̄ al-Nūn Sufism describes the relationship of love with ma'rifa. This teaching had a very strong influence on later generations such as al-Tusturī (d. 273/283 H), Annakhsyabī (d. 245 H), Ibn Jalak, and al-Khazzār who died in $277 \mathrm{H}^{15}$.

From Persia did appear Abū Yazīd al-Bisțāmī (W. 261 H). He emphasized his attachment to the Qur'an and the Sunnah. His famous teaching reads, don't be fooled by a person who can fly in the air until you see if he is following orders and maintaining the limits of the Shari'a. Some of his words suggest the idea of hulül. He also introduced the terms sukr and 'isyq. Still from Persia, did also appear Yahyā bin Mu'āż al-Rāzì (d. 258 H). He talked a lot about wajd, sukr, and fanā' He said there was no crime. Everything is good because it comes from The Most Good. ${ }^{16}$

After that, the $4^{\text {th }}$ century $\mathrm{H}$ entered. Among the figures of this period were Mūsa Al-Anșārī (d. 320 H), Ahmad al-Ruzbarī (d. 322 H), Abū Zaid al-'Adamī (d. 341 H), Abū 'Alī al-Śaqafĩ (d. 328 H), Abū Bakr al-Syiblī (d. 334 H), Abdullah al-Murta'isy (d. $328 \mathrm{H}$ ), and al-Khuldi (d. $348 \mathrm{H}$ ). At the beginning of the fourth century, the orders (tariqa) began to emerge. Hamka called the order as a learning system for Sufism ${ }^{17}$. The location of the order is usually chosen in a remote place. The teacher is called alShaykh or al-Murshid. Murshid has tried by himself the method of pursuing the goal of Sufism and succeeded in improving the quality of the soul. Because he is successful, it also deserves to be taught. This method includes the practice of dhikr and wirid with a certain amount ${ }^{18}$. The orders that emerged during this period included:

- TTaifüriyyah which is attributed to Țaifür, namely Abū Yazīd al-Bisțāmī

- Al-Saqațiyyah which is attributed to al-Sarī al-Saqațī

- Al-Khazzāriyyah who was attributed to Abū Sa'īd al-Khazzār

- Al-Nūriyyah which is attributed to Abū Husain al-Nūrī

- Al-Malāmatiyyah which is attributed to Ḥamdūn al-Wașșār

15 Hamka, 122-24.

16 Carl W. Ernst, Sufism: An Introduction to the Mystical Tradition of Islam (Berkeley: Shambhala, 2011), 21.

17 Ernst, 133.

18 Order is a kind of ijtihad in terms of the obedience to Allah. 
In the $4^{\text {th }}$ century, the description of physical and mental knowledge began to sharpen in 4 terms, namely sharia, țariqa, haqiqa and ma'rifa. Sharia is the discussion of law. All laws governing someone's actions are included in the Sharia. There are two kinds of Islamic deeds; ta'abbudī and ta'aqqulī. Shari'a ta'abbudi covers all acts of worship such as the number of rakaat prayers, the hajj procedure, the month of Ramadan as the month of fasting and others. Ta'abbudi is an aspect of dogma in Islam. Shari'a ta'aqquli can be rationalized and continue to evolve according to the times and places. Tariqa means path. Because the aim of the implementation of the Shari'a is God's, there is a journey between servant and Allah. There is a way to go. The path taken is called țariqa. From here, inner knowledge began to enter. There are conditions for taking this path such as sincere, murāqabah, muhāsabah, tajarrud, 'isyq, and hubb.

Haqiqa means absolute real truth. The meaning is a person who succeeds in taking tariqa has the end of the path to gain haqiqa. The sign of reaching haqiqa is that first the kasyaf is achieved, that is, the secret between the servant and Allah. The veil, the wall of lust that stands between the servant and Allah, is gone. It begans to have ikhtilaf at this point among the Sufis. There are those who have the thought of hulül. Some have rejected it and have suggested the term ittișāl. Ma'rifa means the peak of knowledge. If science and knowledge only find out the state of something, then ma'rifa finds out its cause and value. If science teaches $2+2=4$, then ma'rifa asks "Why four?" "Who made it 4?" The set of knowledge about sharia, țariqa, and haqiqa is ma'rifa. In other words, ma'rifa is a set of knowledge, feelings, experiences, deed and worship.

This journey will eventually form our perfect human beings. People are getting closer to Allah and finally Allah will be their sight, hearing and hand. They become auliya' (friends of Allah) and cando magical things. These auliya'get karamah like the prophets get miracles ${ }^{19}$. Waliyullah, according to Sufis, can get in touch to the supernatural realm ${ }^{20}$. At this time, a strong clash between Sufism and Fiqh started to emerge. The examples of the conflicting understanding between Sufism and Jurisprudence in that era is that Fiqh taught sunnah prayers (salah) at certain times, Sufism performed sunnah prayers up to hundreds of rakats. Fiqh taught prayers based on the $m a$ 's $\bar{u} r$ tradition, while Sufism made up additional prayers.

During this period, there was also an incident that shocked the world of Sufism, namely the Al-Hallāj incident (244-309 H). Al-Hallāj is a symbol of the clash between Sufism and fiqh that is very sharp. Hundreds of jurists opposed him and hundreds of jurists defended him. Those who fought against him were among others: Ibn

19 Hamka, Perkembangan \& Pemurnian Tasawwuf Dari Masa Nabi Muhammad Hingga Sufi-Sufi Besar, 139.

20 Hamka, 140.

Teosofia: Indonesian Journal of Islamic Mysticism, Vol. 9, No. 2, 2020 
Taymiyah, Ibn Qayyim and Ibn al-Nadīm. ${ }^{21}$ Examples of scholars who did not dare to criticize him were Ibn Syuraiḥ, al-Gazzālī, Jalāluddīn al-Rūmī, Farīdudd̄̄n al-'Atțār, Abdu al-Qādir al-Jīlān̄i, and al-Damīrī. The fịh scholars who opposed Al-Hallāj called this figure misguided. Sufis who oppose them address the jurists as ahlu al-zawāhir or ahlu al-rusūm. Al-Hallāj's works, according to Ibn Al-Nadīm, are 47 pieces in total. Orientalists took great care of him. Among those most notable ones was Louis Massignon in the work entitled La Passion D'al-Hosayn-Ibn-Mansour Al-Hallaj: Martyr Mystique De I'Islam, Exécuté $A$ Bagdad Le 26 Mars 922; Étude D'histoire Religieuse. The teachings of Al-Hallāj influenced the next Sufis such as Ibn 'Arabī, Ibn al-Fārị̣, Jalāluddīn al-Rūmi, al-Suhrāwardī, and Ibn Sab'īn.

On 18th of Żulqa'dah $309 \mathrm{H}$, al-Hallāj was executed during the Abbasid Caliphate, namely the Caliph of al-Muqtadir Billah because it was considered that his teachings damaged the principal of Islamic teachings. First, he was flogged, then crucified, then his hands and feet were cut off, then he was beheaded, then the pieces of his body were hung at the city gate of Bagdād, then burned and his ashes thrown into the Tigris river. Therefore, it can be concluded that the $3^{\text {rd }}$ and $4^{\text {th }}$ centuries $\mathrm{H}$ was the peak of the dispute between Sufism and Fiqh.

\section{E. The Fifth Century}

In the $5^{\text {th }}$ century, an intellectual gigantic figure was born who reunited between Sufism and Fiqh, even with Philosophy. This person was al-Gazzālīin ${ }^{22}$. Al-Hallāj's death on the cross made a very bad impression on Sufism. Moreover, there was a kind of similarity between Sufism and Ismäiliyyah/Bäținiyyah that has the belief of an invisible priest. This belief was similar to the Sufis notion who believe that whole world is regulated by a wat (friend of Allah). In the midst of chaos like this, al-Gazzālī arose uniting all the divisions of the various approaches. Zwemer said that after the Prophet's death there were two great people who contributed to muslims world. First, al-Bukhārī who collected the traditions of the Prophet Second; al-Gazzālī who elaborated detaily the teachings of Prophet Muhammad

Al-Gazzāli studied various kinds of knowledge until he became an expert. He studied fiqh and uṣūl fiqh until he could wrote al-Muṣtașfā. He studied the knowledge of kalam until he became a true expert and knew the dangerous points so that the book of Iljāmu al-'Awāmm 'an 'Ilmi al-Kalām was born. He reviewed Philosophy to know its weaknesses so that the book Tahāfut al-Falāsifah was born. He studied Bātiniyyah until

21 Arjan Post, “A Glimpse of Sufism from the Circle of Ibn Taymiyya," Journal of Sufi Studies 5, no. 2 (2016), https://doi.org/10.1163/22105956-12341289.

22 Post, 161. 
he understood the falsity of this teaching and wrote specific book about it. ${ }^{23}$ All of that knowledge did not satisfy the thirst of his soul until he finally encountered Sufism.

The interesting thing about Sufism for al-Gazzāli is because Sufism is not only based on reason. What really appealed to him was the training of the soul, that is, the practice of imparting a praiseworthy character and resisting the impulses of despicable appetence. Even though he knew the mistakes of previous Sufis, he was optimistic that all these mistakes could be corrected as long as two things were always handled, namely knowledge and good deed. He studied the spiritual aspects of Rasulullah the companions, even the life of Prophet Isa. He studied Sufism legacies such as Qūtu alQulūb by Abū Țālib al-Makkī, works of al-Ḥārỉs al-Muhāsibī, al-Junaid, al-Syiblī, Abū Yazīd al-Bisțāmīe even al-Hallāj. Finally, he concluded that Sufism was beautiful and incredible. Finally, he decided to compose the book Ihyā 'Ulūmiddin which married Sufism with Fiqh and even kalam knowledge ${ }^{24}$.

\section{F. The Sixth and Seventh Century}

In the $6^{\text {th }}$ century, after the time of al-Gazzāli, a new school of Sufism was born called philosophical Sufism. This type of Sufism wants to open the veil between servant and God, not using cleansing the soul and longing for God, but opening the hijab with philosophy ${ }^{25}$. It is known that the purpose of Sufism is to draw closer to Allah. The purpose of getting close to Allah is that, for some people, until they feel that they are connected and for some others, until they feel that they are united. The path taken is inner cleansing, love, longing, contemplating one's weaknesses and contemplating the majesty of Allah. Therefore, the main path of Sufism is feeling, while reason is number two. In contrast to philosophy, it prioritizes reason. ${ }^{26}$ Thus, the flow of Sufism that emerged at this time could be said to be a completely new flow that had never been known to Sufism before because it tried to marry reason with feelings to achieve the goal of Sufism. However, although Sufism and philosophy are in principle different, there are several branches of science that are equally devoted to Sufism and philosophy, namely ethics, aesthetics, psychology and metaphysics. The existence of philosophers who support Sufism, such as al-Gazzāli and Ibn 'Arabī made Sufism's dignity rise ${ }^{27}$.

At this time, the terms kasyaf, tajalli, wahdah muṭlaqah, hulūl, mujāhadah, karāmah, and shatahāt began to appear more frequently. The meaning of shațạāt is

\footnotetext{
23 José Bellver, “'Al-Ghazālī of Al-Andalus': Ibn Barrajān, Mahdism, and the Emergence of Learned Sufism on the Iberian Peninsula," Journal of the American Oriental Society 133, no. 4 (2013): 65981, https://doi.org/10.7817/jameroriesoci.133.4.0659.

24 Bellver.

25 Bellver.

26 Arthur John Arberry, Sufism: An Account of the Mystics of Islam (England: Routledge, 1950), 120.

27 Arberry, 213-15.
} 
Sufi words which cannot be taken literally because their literal meaning indicates kufr. Syațahāt arose out of such a passionate drunkenness that it seemed like he was not aware of what was being said. The examples of syat ạhāt are the utterance of subhāñ̄,

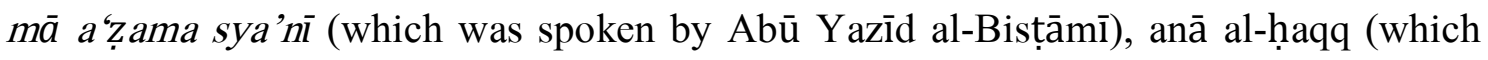
was spoken by Al-Ḥallāj). The works of Suhrāwardī, Ibn al-Fārị̣, Jalāluddīn al-Rūmī, Ibn 'Arabī, al-Syīrāzì contain a lot of the syaṭahāt words.

At this time, the term wah with various levels also began to appear such as wati quțb/ra'sul 'ārifīn, abdāl and others ${ }^{28}$. Ibn Khaldūn in his muqaddimah said that the belief of waĭ with various authorities is influenced by Bäținiyyah/Ismā'iliyyah/ Rã fịah/Shia thoughts. Some of the most important figures at this time were alSuhrowardī (d. 586/587 H), Muhyiddīn Ibn 'Arabī (d. 638 H), Ibn al-Fāriḍ (d. 632 H), and Ibn Sab'īn (d. $669 \mathrm{H})$. In modern times, Iqbal the poet can be classified as followers of philosophical Sufism, to be precise followers of al-Rūmì. However, his Sufism is an eclectic Sufism which emphasizes a return to the Al-Qur'an. It can be said that Iqbal tried to combine Sufism of al-Gazzāli, Ibn Taimiyyah, Ibn 'Arabī, and Jalāluddīn alRūmī. ${ }^{29}$ Natsir praised Iqbāl as a bridge between Western philosophy and Eastern sense. During this period ( $6^{\text {th }}$ and $7^{\text {th }}$ centuries), various suluk orders (tariqa) also flourished. An order is like a boarding school in our country where students are trained under the guidance of teachers. Apart from studying religion, the most important thing in the order is that students learn wirid to reach God. The names of the orders are usually assigned to the name of the Shaykh.

Among the well-known order is the Qädiriyyah order which is attributed to Abdul Qādir Al-Jīlānī (d. $561 \mathrm{H})$. There is also the Rifâ'íyyah order which was attributed to Ahmad al-Rifā'ì (d. $570 \mathrm{H}$ ). Part of strange teachings of this order is to train its students to be fire resistant, resistant to being injured, to be resistant to being pecked by snakes and to walk on glass. If all is not felt, then they are considered to have reached fanā'. Another order is Suhrawardiyyah who was attributed to Abū Ḥaș

28 There are various opinions among the Sufis. Some say that the highest level of waß is called Gauis. There is only one in every era. Lower than Gaus is watad/autād. Four in total. Each character is in the four cardinal directions to protect them. Lower than watad is qut b/aqtāa. They are 7 in total. Each guards 7 continents. Underneath is badal/abdāl. The total is 40. Every time one dies, one will immediately be replaced with a new one so that the number remains 40 . Under abdal is naj̄ $b /$ nujabä' which number is to 300 . Sometimes they are called nuqabā'/naqīb.

Ordered from the top, the levels are as follows:

1. Gauś (الغَوْثُ)

2. Watad/autād(الأَوَتَادُ)

3. Quṭb/Aqțāb (الأَقْطَابُ

4. Badal/Abdāl(الأَبْدَانُ)

5. Naj̄̄b/Nujabā'/Naqīb/Nuqabā'(النُّجَبَّاءُ)

See: Jāmi 'al-Ușūl fi al-Auliyā' wa Anwā 'ihim wa Auṣā fihim by Ahmad al-Naqsyabandī al-Khālidī.

29 Eric Geoffroy, Introduction to Sufism: The Inner Path of Islam (Perennial Philosophy) (Indiana: World Wisdom, 2010), 104. 
'Umar al-Suhrawardī (w. 638 H), author of the book 'Awārifu al-Ma'ârif. Another order is called Syāżiliyyah which is attributed to 'Alī al-Syāżilī (d. 655 H). One of his wellknown followers is Ibn 'Ațā'illāh al-Iskandarī, author of the book al-Ḥikam. ${ }^{30}$ Another order was named Maulā wiyyah who was attributed to Jalāluddīn al-Rūmī (d. 672 H). The term pupil in this țariqa is called Darwīsy (this is Persian, because al-Rūmī is indeed a Persian). The prominent characteristics are song and dance. The followers of this order are mostly highly educated. Another order called Badawiyyah which was attributed to Ahmad al-Badawī (d. $675 \mathrm{AH}$ ) and appeared in Egypt.

\section{G. The Eighth Century}

After entering the $8^{\text {th }}$ century until today, it can be said that there has been no significant development of Sufism even though there are Sufi authors who wrote down their thoughts such as al-Kasysyani $(\mathrm{d} .739 \mathrm{H})^{31}$. During this period, a book that shocked the scholars of fiqh entitled Insān Kāmil by Abdu al-Karim al-Jīlì (d. 826 AH) appeared. However, we still cannot say this work is a new thought, because it just details, expands and beautifies the thoughts of Ibn 'Arabī and Jalāluddīn al-Rūmì only. ${ }^{32}$

During this period, the growth of the order was getting faster. Each shaykh establishes his own order. North Africa is the country that produces the most orders. The entry of Islam to Indonesia was also in the atmosphere of the order. Hamka's father noted that in Indonesia there were 41 orders which he recorded in 1908. In the $10^{\text {th }}$ century, the great Egyptian Sufi named Abdul Wahhāb al-Sya'rānī appeared. He wrote many books. However, according to Hamka, if we read it, there are many things that are difficult to be accepted by reason, even by the sense ${ }^{33}$. In the $12^{\text {th }}$ century, Abdul Gan̄̄ al-Nābulusī (d. 1143 H) appeared. His thoughts also was nothing new. Just follow Ibn 'Arabī only.

\section{H. Summary of the Schools of Sufism}

The classification of Sufism schools is a matter that cannot be agreed as a consensus because each person can categorize it with various points of view. Besides, the sources of Sufism and its various thoughts also give rise to different potential categories. Therefore, historical studies related to the schools of Sufism can present data on the various classification of Sufism according to the scholars who categorize

30 Alexander Knysh, Sufism: A New History of Islamic Mysticism (New Jersey: Princeton University Press, 2017), 236.

31 Hamka, Perkembangan \& Pemurnian Tasawwuf Dari Masa Nabi Muhammad Hingga Sufi-Sufi Besar, 261.

32 Leonard Lewisohn, Classical Persian Sufism from Its Origins to Rumi (700-1300) (London: Oneworld Publications, 1999), 527.

33 Lewisohn, Classical Persian Sufism from Its Origins to Rumi (700-1300); Hamka, Perkembangan \& Pemurnian Tasawwuf Dari Masa Nabi Muhammad Hingga Sufi-Sufi Besar, 261. 
them. There are those who classify the schools of Sufism into 2, 3, 6 and so on. Ibn Taymiyah, for example, classified Sufis into only 3 types, namely Süfiyyatu al-Haqā 'iq

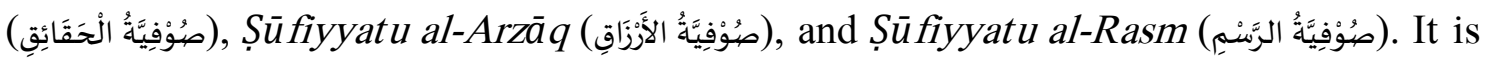
also possible to classify the schools of Sufism according to their thought tendencies such as al-Isyrāqū, Hulūlschools, Waḥdatul Wujūd schools, and so on. Moreover, if the criteria of the schools uses the order standards, the number can be hundreds or thousands.

As for the classification of the schools of Sufism into akhlāqī/sunni sufism, philosophical sufism, irfānī sufism, ruhbānī sufism, or sȳ̄' sufism, it seems that that is the classification that had emerged in modern times. Some journals mention the term akhlaqi and philosophy Sufism. However, when I tried to trace the origins of this category, I had not found the first authoritative thinkers to suggest it. Therefore, I decided to "create my own category" based on Hamka's book on the development of Sufism. Hamka himself never classified the schools of Sufism. He only described the development of Sufism from time to time with an analysis of their respective styles. ${ }^{34}$ On this basis, some of the schools of Sufism that will be presented below are categorizations based on a description of the historical approach by taking the characteristics of each style of Sufism into account.

Sufism schools from the early days of their growth to their decline can be classified into several types, namely:

- Rajā' wa Khauf Sufism

- Mahabbah Sufism

- Happy Sufism

- Al-Ḥallāj Sufism

- Al-Gazzālī Sufism

- Philosophical Sufism

- Ibn Taimiyyah's Sufism

Sufism of Raja' wa Khauf is Sufism of Ḥasan Al-Bașrī (d. 21-110 AH). AlSya'rānī said that due to the fear of Hasan al-Bașrī to Allah, he felt that hell was created only for him ${ }^{35}$. Mahabbah Sufism is Sufism of Rabī'ah al-'Adawiyyah (d. 185 H). Mah abbah Sufism is considered higher than Raja' wa Khauf Sufism. It is said that Rabì'ah al-'Adawiyyah had heard someone mention the torments of hell so that she took istighfar until she passed out. After she became conscious, she said, "I have to ask forgiveness in a way beyond my first way." ${ }^{36}$ Sufism poetry on the theme of God's love that was raised by Farīduddīn al-'Aț̣ār, Ibn al-Fārị̣, al-Ḥallāj and Jalāluddīn al-Rūmī

34 Herman L. Beck, "The Contested State of Sufism in Islamic Modernism: The Case of the Muhammadiyah Movement in Twentieth-Century Indonesia," Journal of Sufi Studies 3, no. 2 (2014): 183-219, https://doi.org/10.1163/22105956-12341269.

35 Beck.

36 Beck, 192. 
were all preceded by this Rabī'ah al-'Adawiyyah ${ }^{37}$. Heaven or hell is not at the upmost consideration or not being considered at all because the main thing is love/mahabbah. The goal of this love is musyāhadah ${ }^{38}$. His famous words read,

$$
\text { اللَّهمَّ ، إِنْ كنتُ أعبدُكَكَ طمعًا في جنَّتك فاحِرِمنني منها ، وإِنْ كنتُ أعبدُك خوفًا مِنْ نارك فيانْ }
$$

That is:

"O Allah, if I worship You because I want your heaven then prevent me from entering it and if I worship you out of fear of Your hell then burn me in it"

Ma'rūf al-Karkhī differs slightly from Rabī'ah al-'Adawiyyah. Although he agreed to Mahabbah Sufism, for him, the goal was țuma'ninah (peace of mind). In other words, it is the wealth of the heart that is being pursued ${ }^{39}$. Haarisis al-Muhāsibī as one of Mahābbah Sufism sufis argues that his goal is the union between the loving and the beloved ${ }^{40}$. Happy Sufism is Sufism of Abū Bakr al-Syiblī. He taught never to complain about life. Human wickedness and deception should be addressed with the teaching of "Live like a tree with fruit on the side of the road. It is thrown a stone, but in return it gives a fruit." Sufism of al-Hallāj is Sufism that collides with Fiqh. The main teachings of al-Hallāj which cause strong opposition are:

- $\quad$ Al-Hu ulūl, namely divinity/lāhūt incarnating to insan/nāsūt

- Al-Haqīqatu al-Muhammadiyyah, namely Nūr muhammad as the origin of deeds and knowledge and the reason for the creation of the universe

- Unity of all religions

Here is the detail of the hulül. If people want to purify themselves, they will always level up; from muslim to mukmin to salihin then muqarrabìn. The muqarrabin level is the closest to Allah. After that, servant and God unite. If they are united, they can no longer be distinguished and what happens is the will of God, not the servant. The Spirit of Allah covered him as when the spirit covered Jesus, the son of Maryam, so that what was desired was what happened. The nature of unity is like khamr with water or iron with fire. This is the meaning of his popular statement, "Anā al-haqq", "Wa mā fi jubbatī illā Allāh". On the other hand, Al-Hallāj stigmatized anyone who says that divinity can be mixed with humanity as unbeliever.

From this point of view, the teachings of al-Hallāj meet the Christian teachings to believe in God's spirit in Prophet Isa. However, Al-Hallāj does not limit the union between the servant and God to Prophet Isa alone, but such a thing can happen to anyone who is able to fuse himself on Allah so that he gets the baqā' of Allah. Nūr Muhammad is believed to be the origin of all events. Similar to the reflection of the philosopher who concludes that the origin of all things is the First Cause. According to

\footnotetext{
37 Beck, 192-93.

38 Beck, 195.

39 Beck, 216-17.

40 Beck, 217.
} 
him, the Prophet Muhammad had two forms, namely the form of qadim and azali and the form of a human. The form of qadim is Nūr Muhammad, from which all the prophets and wat were taken. He preceded al-qalam. All knowledge is only a drop from the ocean of his knowledge.

Regarding religions unity, he argued that all religions, even though they have different names, are in essence only one. All goes towards Allah. This thought is very close to the Ismà 'iliyyah/Bäținiyyah thoughts. Al-Gazzāli Sufism is the concept which marries and seeks to reconcile between Sufism and Fiqh which had a violent clash in the $3^{\text {rd }}$ and $4^{\text {th }}$ centuries. Some of al-Gazzāli's thoughts on Sufism can be briefly described as follows. Ma'rifa on al-Gazzālī's point of view is the knowledge of knowing Allah. This is true knowledge and it cannot be obtained solely with reason. Everything that exists is an expression of God's deeds. Allah and his deeds are two not one. Thus, from this point of view, al-Gazzālī is different from al-Ḥallāj. Al-Gazzālī refused the wahdatul wujū $d$ idea. If the nature of ma'rifa is clear, then it will lead to happiness. For philosophers, this is called heaven. For ahlul haqq, this is the reason that makes people deserve to go to heaven.

For al-Gazzālī, humans will always be different in terms of capacities and abilities. There will always be laymen and higher ranks. The layman just needs to hold the clear ones. Do not try to jump into complicated things, because a layman's decision to dive into complicated matters is like a person who cannot swim but recklessly jump into the ocean. Such a decision only ends up perishing. There are also people who have immature knowledge. Their basic knowledge have not yet reached the level of maturity. As the result, their religion is full of doubts.

Based on obvious differences like that, al-Gazzālī divided human faith into 3 levels. The first level is the laymans' faith. The laymans' way of faith is just by news and information. The second is the intellectuals' faith. The way they have faith is by receiving news that is corroborated by proof. He compared, researched, and examined the signs of that truth. The third level is the 'arrifin faith. This is the highest level of faith because they believe in something after witnessing it by themselves. The path to the highest level of faith is to throw away all the splendor of the world, raise himmah, enlarge love and walk the path to Allah ${ }^{41}$. If this path is taken seriously, it will reveal the veil little by little so that musyāhadah arises. This vision is with the heart, not the eyes. In this phase, you can see all those which are invisible such as lauh mahfüz, qalam, 'arasy, and all the realms of kingdom in the heavens and on the earth.

Here, al-Gazzālì admitted that the way to the ma'rifa cannot be achieved by the knowledge of kalam, philosophy, moreover Bäținiyyah. Yet, the proven path is Sufism. Those who reach that level are wah. The wat level is below the prophet. If the prophet gets revelation, then the wa/ gets inspiration/ilhām. Ilhām can come from

41 Perhaps Al-Gazzāli meant taking the path to Allah is taking the path to get to know Him. 
dreams, meditation, and can even come from abstract voices. This immaterial sound is called hätif. Ma'rifa is also related to happiness which is one of the important themes in philosophy. For al-Gazzālī, the sources of happiness can be many things. One of the sources is coming to know after being stupid. There are two levels of happiness, namely lażżāh (delicacy) and sa'âdah (happiness). The peak of satisfaction and happiness is if you get knowledge of knowing Allah (ma'rifatullah). ${ }^{42}$

This explanation is rational. The argument is also rational. Here's the description. The delicacy of the eye is to see, the delicacy of the ear is to hear, the delicacy of the skin is to touch. They can only function if the soul is still there. The center of all physical delicacy is in the heart. Therefore, knowing Allah becomes the peak of happiness because it is the source of all satisfaction. Like a person who is happy to know the prime minister, his happiness will be even higher if he knows the king. Therefore, knowing the King of the kings is the peak of happiness. Thus, alGazzāli invites Sufism with the aim of knowing Allah with the effect of mental happiness and that must be achieved in a strict way using the guidance of the Prophet

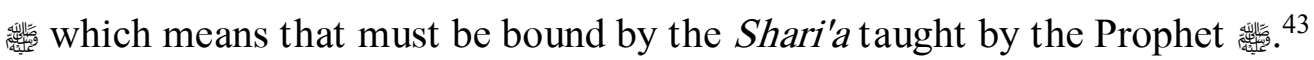

Philosophical Sufism is Sufism which seeks to marry between Sufism and Philosophy to achieve the goals of Sufism. Each philosophical Sufism character has a distinction that distinguishes it from other figures. Each of the characteristics of the Philosophical Sufism can be briefly described as follows. Al-Suhrawardī (d. 586/587 $\mathrm{H})$ is known as the initiator of Hikmatu al-Isyrāq. His title is al-mu'ayyad bi almalakūt. His nickname after he died is al-Shaykh al-Maqtūl. He studied Greek, Persian and Indian philosophy. The results of his studies were expressed in a number of works such as Hikmatu al-Isyrāq and Hayākilu al-Nūr. In the book Hikmatu al-Isyrāq he introduced his philosophical Sufism conception. There are five topics that he brought up. The first is about Nūr and the nature of $n \bar{u} r$. Second, about $n \bar{u} r u$ al-anwār (light from all lights). Third, about the actions of nūru al-anwār and nūr qāhir. The fourth is about the realm of the barzakh, its shape, structure, and strength. The fifth is about the day of the promise, prophecies and dreams.

He argued that the spiritual side is always in conflict with the physical body. He called the spiritual side as $n \bar{u} r$, while the physical realm as zulumāt. He called reason as anwār. The reason that governs falak is called $n \bar{u} r$ qāhir while Allah is called $n \bar{r} r u$ al-anwār. As for jisim he called it the dark jauhar or gasaq while the realm of ajsam is named as barzakh. Al-Suhrawardī argued that all philosophers, wisdom experts or recluses are all one with one goal, namely to seek the light of truth from Allah, from the light of all lights. All paths may vary, but the goal is one. Those who seek solely by

42 Seyyed Hossein Nasr, The Garden of Truth: The Vision and Promise of Sufism, Islam's Mystical Tradition (New York: HarperCollins, 2008), 180.

43 Leonard Lewisohn, The Heritage of Sufism: The Legacy of Medieval Persian Sufism (1150-1500), vol. II (London: Oneworld Publications, 1999). 
reason without any belief are philosophers. Those who seek reason but are limited by religious teachings are mutakallimin. Those who just use feelings and impersonate all texts are Sufis. That who uses feelings but also use reason is isyrā $q$ philosophy.

Al-Suhrawardī's idea is similar to Plato's philosophy. Plato's philosophy prioritizes the Great Creator as the end of human ideals. Al-Suhrawardi greatly admired Plato and dubbed him "Who has hands and light". The seeker of wisdom to him is classified into three. First: Those who seek wisdom using their minds i.e philosophers. Second; who seek wisdom to reach God, i.e. Sufis. Third; Those who use reason and give priority to feel i.e. philosophers of divinity (al-hakim al-ilāhì $)^{44}$. However, his attitude towards hulül is not clear. It seems that he is hesitant or at least does not want to explain it straightforwardly. Therefore, it can be understood that AlSuhrawardī wanted to combine deep Sufism as well as deep philosophy. Thus, his $i s y r a \bar{q} q$ philosophy is neither true philosophy nor true Sufism. He used expressions that could be interpreted for a hundred meanings so that many fiqh scholars opposed him. He was accused of being zindi $q$ and mulhid so that he was killed on the orders of Șalaḥuddin al-Ayyūbì by being starved to death.

As for Muhyiddīn Ibn 'Arabī (d. $638 \mathrm{H}$ ), this figure is very well known as the raiser of the flag of Philosophical Sufism. In his hand, philosophical Sufism reached the "peak of glory". His laqab was al-Hātimī. He was named al-Shaykh al-Akbar and al-Kibrīt al-Ahmar. He was originally Spanish, but lived in Damascus until his death. His grave was visited by many people. His many works show how extensive his knowledge was. Brockelmann recorded 150 pieces of his work. The largest was alFutūḥat al-Makkiyyah followed by Fuṣūṣū al-Hikam and Żakhā'iru al-A'lāq Syarhu Turjumāni al-Asywāq. He was very good at choosing words. He could combine philosophy with Sufism. He was seen to be able to reconcile the abyss of Sufism with philosophy.

The peak of wahdatu al-wujū d idea was on the hands of Ibn 'Arabī. That idea was established from philosophical reflections and żauq Sufism. For him, everything was essentially one. Pharaoh and the prophet are only the expressions of that one. That idea is similar to the mind of Pythagoras which says "The soul of all numbers is one". Ibn 'Arabì also approved of the idea of haqiqah muhammadiyyah. This noor, that is haqiqah muhammadiyyah, is seen as the Nūr of Allah. All realms are originated from this noor whether it is the jabarūt, malakūt, mis̈āl, ajsām, or arwāḥ realms. This noor is in the prophet, wati and all human beings.

Ibn 'Arabì also approved the unity of religions. Indeed, the consequence of wahdatu al-wujūd idea and haqiqah muhammadiyyah is this wahdatu al-adyān thought. A true 'ar rif sees that everything to worship is only a symbol of God. Thus, idols, $K a^{\prime} b a h$, fire, statue or nothingness are not a matter of being worshiped as long as

44 Hamka, Perkembangan \& Pemurnian Tasawwuf Dari Masa Nabi Muhammad Hingga Sufi-Sufi Besar, 187-91. 
they realize the nature of being worshiped. The difference between Ibn 'Arabī and alHallāj: If al-Hallāj believed in that thought as the emanation of feelings, then Ibn 'Arabi believed it was the result of philosophy and ideology. Therefore, if in the time of Al-Hallāj people were still timid about expressing wahdatu al-wujūd idea, then in the time of Ibn 'Arabì, this idea was re-established frankly and challenging without hesitation ${ }^{45}$.

This ideology influenced Akbar Khan in Delhi in the $17^{\text {th }}$ century that he created a religious association called Dīn Ilāhī. In his palace, Christian priests, Hindu pandits and Islamic scholars gathered. However, this idea died along with the death of its founder. Among those that were influenced by Ibn 'Arabì was the theosophical movement founded by Balavatsky and Annie Bessant. In Indonesia, this idea influenced a number of figures in the $16^{\text {th }}$ century such as Hamzah Fansuri in Aceh, Syamsudiin from Sumatra and Siti Jenar from Java. ${ }^{46}$

The reaction of the scholars was very strong against Ibn 'Arabī. They still tried to forgive Al-Hallāj because he was considered lovesick, but they cannot ignore Ibn 'Arabì because he was considered practicing philosophy. In Egypt, he was nearly killed. The opponents were not just any scholars. Among them were Ibn Taimiyyah, Ibn Qayyim, Ibn Khaldūn, ${ }^{47}$ and Ibrahīm al-Biqā'ì. Al-Biqā'ī composed two books to criticize Ibn 'Arabī with the title Tanbīhu al-Gabì 'alā Takfiri Ibni 'Arabì and Tahììiru al-'Ubbād min Ahli al-'Inād bi Bid'ati al-Ittiḥād. There are also many people who defend him and they are not minor figures either. Among them were Majduddīn alFairuza Ābādī, Quṭbuddīn al-Ḥamawī, Șalahuddīn al-Ṣafadī, Syihābuddin 'Umar alSuhrawardī, Fakhruddīn al-Rāzī, Abdurrazīàq al-Qasyanī, Abdul Ganī al-Nābulusī, and Jalāluddīn al-Suyūṭi. To refute al-Biqā'ī, al-Suyūṭi wrote a book entitled Tanbīhu alGabì fi Tabri'ati Ibni 'Arabì. ${ }^{48}$

Interestingly, all critics and defenders of Ibn 'Arabī were also Sufism lovers. In Persia, Ibn 'Arabī's idea was promoted by Jalāuddin al-Rūmī. This idea also influenced Ibn al-Fāriḍ and Ibn Sab'īn. He also influenced Abdul Karim al-Jīlī in his book; alInsān al-Kāmil. Therefore, Al-Gazzāli's effort to combine sufism and fiqh was "torn apart" by the sufism of Ibn 'Arabī with his wahlatu al-wujū d concept. Another figure of philosophical Sufism is Ibn al-Fārị̣ (d. 632 H). He came from Egypt. He was famous with the poem of God's Love. Qașīdah Burdah was influenced by his poems. After Ibn al-Fāriḍ, came Ibn Sabīn (d. 669 H). He is famous with his wahdatu al-wujūd

45 It seems that because of the weakness of the state at that time, they could not take action against Ibn 'Arabī.

46 Hamka, Perkembangan \& Pemurnian Tasawwuf Dari Masa Nabi Muhammad Hingga Sufi-Sufi Besar, 192-200.

47 Semih Ceyhan, "Ibn Khaldun's Perception of Sufis and Sufism: The Discipline of Tasawwuf in Umran," Asian Journal of Social Science 34, no. 3-4 (2008): 483-515, https://doi.org/10.1163/156853108X327056.

48 Nile Green, Sufism: A Global History (United States: Wiley-Blackwell, 2012), 230. 
concept. At first, he studied Fiqh, then switched to Sufism until his death. His Sufism attracted Westerners because his letters to the Persian king; Frederik II, were found. There were four topics that Frederik II asked Ibn Sabin, namely the realm of qadim, ten talks, metaphysics and the soul. Ibn Sabīn's letters answered those questions. Unfortunately, there were a number of sentences that are considered blasphemous from him. When he saw a tawaf person, he once said in a disdainful tone that "a tawaf person is like a donkey wandering around a millstone". He even once said insulting words to the Messenger of Allah "Why Muhammad, the son of Aminah, narrowed the universe by saying there was no prophet after me?" Ibn Daqìqi al-'ìd said, "I was with him one day. I understood each of his sentence. Once they were put into utterances, I didn't understand anymore". People say that his death was due to a suicide because of the harsh mockery of the people. Some say that he was starving because people hated him like the Dutch Jewish philosopher, Spinoza. ${ }^{49}$

As for Ibn Taimiyyah's Sufism, this Sufism tries to clean Sufism from foreign influence and tries to restore it to the basis of Islam, namely Tauhid. For Ibn Taimiyyah, the servant's relationship with Allah must be direct, not using murshid, shaykhs or wah intermediaries. The way to have direct contact with Allah is to follow the instructions of Rasulullah 䊁. If he is consistent, his rank in front of Allah will get higher and he can reach the rank of wai Allah. Ibn Taimiyyah acknowledged the existence of a wai Allah, but strongly rejected the idea of relying on the wati Allah. Therefore, he harshly criticized the rābitah teachings on praying or worshiping. In order to criticize the practice of tawassul which is commonly practiced by Sufis, Ibn Taimiyyah wrote a special book entitled al-Tawassul wa al-Wasīlah. ${ }^{50}$

Those are all efforts to cleanse Sufism from the ideas emerged within the Muslim community. Apart from criticizing the ideas that emerged from Muslims, he also criticized the concept of Sufism which was influenced by the external ideas, namely foreign philosophy or mysticism. Ibn Taimiyyah strongly opposed the idea of wahdatu al-wujü d. Uniquely, Ibn Qayyim- who was actually a student of Ibn Taimiyyah- in the Madāriju al-Sālikīn book, sometimes still defends those who believe in wahdatu alwujū $d$ if they are just drunk in love. However, he still firmly called it a mistake, a derailment and a sign that humans other than the prophet were not infallible. He said the Sufi path was like a big ocean which was very dangerous. Ordinary people should not be dragged there. Only those who boarded Noah's boat would be saved and the boat is to follow Rasulullah According to Muhammad al-Bahī, a professor of Islamic philosophy at al-Azhar University, in his book entitled al-Jānib al-Ilāhī min alTafkīr al-Islāmì as well as the book al-Fikru al-Islāmì al-Hadiś, he stated that Ibn

49 Mark Sedgwick, Western Sufism: From the Abbasids to the New Age (Oxford: Oxford University Press, 2016), 321.

50 William Stoddart and R.W.J. Austin, Outline of Sufism: The Essentials of Islamic Spirituality (Perennial Philosophy) (Indiana: World Wisdom, 2012), 115. 
Taimiyyah was the first pioneer who tried to return Sufism to its roots, namely tawheed.

However, although there is a similar spirit between Ibn Taimiyyah's Sufism and al-Gazzāli's Sufism in terms of the efforts to purify Sufism to its original source, both Sufism have different characteristics. Al-Gazzāli Sufism seems to be aloof from life and have seclusion. As for Ibn Taimiyyah, his Sufism invited him to take part in daily life. When there was a call for jihad, Ibn Taimiyyah gave a direct example by taking up arms and fighting. According to Ibn Taimiyyah, true Sufis are those who work hard. Night is to worship, morning is to work hard and play a role in solving life problems at the individual, community and state level, not running away from life's problems. However, Ibn Taimiyyah's thoughts were opposed by a number of scholars. Among them was Ibn Hajar al-Haitamī (d. $977 \mathrm{H}) .{ }^{51}$

\section{Critical Analysis}

In the $1^{\text {st }}$ and $2^{\text {nd }}$ centuries, Sufism was still clean. It had not been mixed with foreign elements and had not caused problems in the midst of Islamic society. At that time, Sufism with its various tendencies still relied on the Al-Qur'an and Sunnah and was strongly tied to the base of Sufism, namely tauhid. Therefore, a very harsh critic of Sufism like Ibn Taimiyyah still praised the Sufi of this early generation. The examples of early generation Sufis praised by Ibn Taimiyyah were al-Junaid, Abū Sulaimān al-Dārānī, Ma'rūf al-Karkhī, and al-Fuḍail bin 'Īyāọ. Those true Sufis, if they performed ijtihad then did mistakes, Ibn Taimiyyah still praised them by calling them mujtahidūna fi țā'atillāh. Ibn Tamiyyah said ${ }^{52}$ :

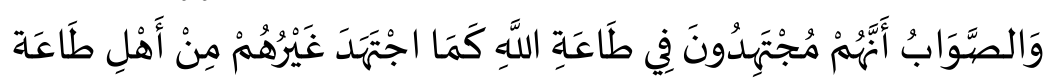

In the $3^{\text {rd }}$ and $4^{\text {th }}$ centuries, a clash began to occur between Fiqh and Sufism. This collision is not necessary, and not supposed to happen. In fact, the hadith about Islam, faith and ihsan gives an impression that Fiqh and Sufism are always side by side. In order to make servants' Islam to be good, fiqh must be studied. In order to have a good faith, Ușuluddin must be learned. In order to have a good $i ̣ s_{a} \bar{n}$, it is necessary to learn Sufism.

Indeed, Sufism is a school of sense (żauq). It uses more inner experiences and it is not the science based on logic and rationality. Scientists discuss about what and how while Sufis discuss from where and to where. Their famous saying reads: man lam yażuq lam ya'rif. They prefer to use the term ma'rifa rather than science. For the Sufis, 'alim people are still under the $\bar{a}$ rif ones. ${ }^{53}$ They practice the hadiths which sometimes

51 Stoddart and Austin, 308-13.

52 Ahmad bin Abdul Halim Ibnu Taimiyyah, Majmu' Al-Fatawa, vol. 11 (al-Madinah al-Nabawiyyah: Majma' al-Malik Fahd li Thiba'ati al-Mushaf Asy-Syarif, 1995), 18.

53 Hamka, Perkembangan \& Pemurnian Tasawwuf Dari Masa Nabi Muhammad Hingga Sufi-Sufi Besar, 106-7, 111. 
according to Fiqh experts are invalid and hold them because they feel they have proven their usefulness. They also practice the Qur'an or hadith which have no specific argument, but they feel the real benefits. This type of knowledge is passed down from generation to generation and does not go through the path of knowledge such as Fiqh. An example of books that collects those experiences is al-Mawāqif by Abdul Qādir alJāzirī. Those actions are extracted from the tradition of the companions who healed with Al-Fātihah even though the Prophet did not teach them to do so. It also strengthens the experience of Ibn Qayyim who did tawaf, felt fatigued, then recited alFatiha $h$ and immediately his fatigue was gone. ${ }^{54}$ Thus, if this is the nature of Sufi's thinking, then Sufism and Fiqh should indeed be able to be brought closer and even married. As al-Gazzāli analysis; Sufi mistakes before the $5^{\text {th }}$ century can be corrected as long as holding two things: knowledge and good deed.

Once the time of al-Gazzālī arrived, the conflict between Sufism and fiqh could be reconciled. Al-Gazzālī's influence in the Islamic world was enormous. Mājid alKailāni in his book entitled Hākażă Zahara Jūlu Ṣalāhuddin even emphasized that the victory of the Islamic army against the crusaders was due to Al-Gazzāli's merit with his book; Ihyā' 'Ulūmiddinn. This book is a book that is considered incredible because it is able to marry Sufism and Fiqh. Until this day, we still witness the influence of alGazzālī's Sufism which is so great that his books on Sufism such as Minhāju al-'Ābidīn and Ihyō' 'Ulümiddīn are studied in Islamic boarding schools.

However, al-Gazzāli's Sufism has got a little criticism from Yusuf al-Qaradāāī. What was highlighted from al-Gazzālī was his thoughts on kasyaf. According to alQaradāāì, kasyaf does exist, yet it cannot be a goal, aspiration, aim, target, something to be pursued, something to desire, something to ask, something to seek or something to wait for. It is also not supposed to be the reason for leaving talabul ilmi which is the path of the Prophet's heirs because the kasyaf can come or not. In short, it must not be a method of seeking knowledge. Seeking knowledge by means of Sufism also cannot

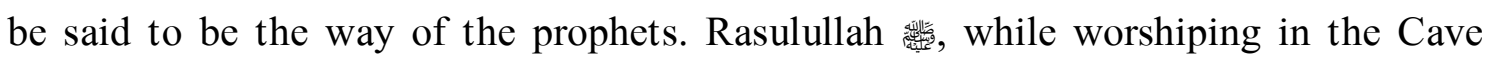
Hirā', did not seek kasyaf or inspiration. Neither did he wait for a revelation from heaven nor expect to be a prophet. In fact, when he got the revelation, he was very surprised, shocked, his heart violently trembled and even worried about his psyche that he asked his wife to cover him with blanket.

Shari'a orders are not looking for kasyaf, but seeking knowledge. Who is struggling to study, then Allah makes it easy for him to walk the path to heaven. Angels are happy with those who seek knowledge and lay their wings on them. There is no evidence that angels lay wings on the seeker of the kasyaf. Kasyaf is nothing more than busyrā 'àjilah to strengthen the heart so that people are steady and have no doubt of being on the right path and continue to istiqamah obeying Allah in that way

54 Hamka, 108-10. 
until the end of life. This is no different from other promises of Allah which are more worldly, such as abundance of wealth, healthy body, many children, a peaceful life, and so on. True worship is pure solely because of Allah and seeking His pleasure. A person who worships because he is looking for kasyaf, means that he is worshiping for his own sake (yațlubu haz̧a nafsihī). People who pray, fast and worship for 40 days because they hope that wisdom will radiate from their heart, meaning that their worship is not sincere because of Allah, but sincere because of wisdom! Thus, a person who worships because he pursues kasyaf means that he is worshiping for kasyaf.

Moreover, the Sufi path of gaining knowledge by means of the kasyaf offered and praised by Al-Gazzālī is a very steep, very dangerous path, many curves, and is a big chasm. People can get hallucinations, schizophrenic, fantasize 20 years and feel it is kasyaf. Sense hurts, the body hurts. Age up while goals have not been reached. People who take it rarely get directions because the path taught by the Prophet was abandoned. Al-Gazzālī himself admitted that a number of scholars criticized the kasyaf seekers and he did not deny this at all. This shows that the criticism is indeed valuable. ${ }^{55}$

Moreover, the kasyaf sometimes contradicts the Islamic law. Supposedly, if that is the case, the kasyaf must be discarded and the argument of the shari'a must win even though it is zannī. Some Sufis do not want to do this because they think that kasyaf is qaț'i and knowledge that is classified as ainul yaqin. This is what will destroy religion. Moreover, this path of pursuing the kasyaf is not the path of the Sahaba, Tãbiinn, and Täbi'ut Täbilnn. If this path was taken, there would be no conquest, no spread of Islam, no spread of the Qur'an, no spread of hadith, and no spread of Fiqh. Islam is a universal da'wah, gathering the world and the hereafter, collecting material and spirituality, knowledge and faith, mind and heart, the rights of Allah and the rights of servants. Guidelines for achieving this are the Qur'an, hadith, and the examples of salaf salih. If people just wait for kasyaf and faid, then that also exists in Hinduism and Christianity. Many of their magical stories related to such things. However, muslims have agreed that they went the wrong way.

After all, how can we guarantee that kasyaf is from Allah, not from Satan? People may feel that they have got the truth even though it is from Satan, if they do not return to al-Rahman's guidance. Therefore, the sālikin, those who travel the kasyaf path, have two opportunities between experiencing aḥū 1 rahmāniyyah and ah wā 1 syaitäniyyah. Moreover, by assuming that this path is worth taking, it only applies to people who have not been visited by the apostles. If the apostle has been sent, then whoever takes another path will get lost. Moreover, it is still possible to understand that the inspiration and kasyaf are given by Allah solely as a grace, not because of

55 Abu Hamid Muhammad bin Muhammad Al-Ghazzali, Ihya' Ulumiddin, vol. 3 (Beirut: Daar alMa'rifah, 2005), 20. 
taking a certain order. With the evidence, many people get inspiration even though he is not a $s \bar{a} l i k^{56}$

\section{J. Conclusion}

This study reveals that Sufism has developed significantly and even changed since its inception. By considering the characteristics of each order, Sufism can be classified into several schools such as Rajā 'wa khauf Sufism, Mahabbah Sufism, Happy Sufism, Al-Hallāj Sufism, Al-Gazzā İ Sufism, Philosophical Sufism, and Ibn Taimiyyah Sufism. Sufism at the beginning, in the first and second centuries of Hijra, such as Mahabbah Sufism and Rajā 'wa khauf, did not lead to a debate as it is still pure and far from the influence of foreign elements and has a strong foundation from the Quran and Sunnah.

But, in its further development, i.e. in the third and fourth centuries, there was a clash between fiqh and Sufism. This is supposed not to happen because they could coexist. Muslims need fiqh as guidance of worship to God. Meanwhile, Sufism also has an important role in guiding Muslims to get perfection (ị̣sān). Sufism and fiqh have to be brought closer and even united. Al-Gazzāli said that the wrongdoings practices of Sufism before the $5^{\text {th }}$ century can be fixed by holding on two principles that are knowledge and good deeds. During his time, the conflict between Sufism and fiqh could be reconciled because the influence of Al-Gazzāli in the Islamic world was very vital.

Whereas Sufism in the fifth century, at the time of Al-Gazzālī, was the most beautiful period in the history of Sufism because both of them could be integrated. But, Sufism in the next period began to experience another conflict due to the influence of philosophy in Sufism until the time of Ibn Taimiyyah who wanted to return Sufism to its origin.

56 Yusuf Al-Qaraḍ̄āī, Mauqifu Al-Islām Min Al-Ilham Wa Al-Kasyf Wa Al-Ru'ā Wa Min AlTamā 'im Wa Al-Kahānah Wa Al-Ruqā (Kairo: Maktabah Wahbah, 1994), 103-11. 


\section{Bibliography}

Al-Bākistānī, Iḥsān Ilāhī Zahīr. Al-Tașawwuf Al-Mansya' Wa Al-Maṣādir. Lahore: Idāratu Turjumān al-Sunnah, 1986.

Al-Ghazzali, Abu Hamid Muhammad bin Muhammad. Ihya' Ulumiddin. Vol. 3. Beirut: Daar al-Ma'rifah, 2005.

Al-Gumārī, Al-Zamzami bin muhammad bin Al-Shidiq. Al-Intișār Li Tañqi AlȘūfiyyah Al-Akhyār. D. Cairo: Dar al-Marjan al-Thaba'ah, 1979.

Al-Qaraḍāwī, Yusuf. Mauqifu Al-Islām Min Al-Ilham Wa Al-Kasyf Wa Al-Ru'ā Wa Min Al-Tamā'im Wa Al-Kahānah Wa Al-Ruqā. Kairo: Maktabah Wahbah, 1994.

Al-Qusyairi, Abdul Karim bin Hawāzin bin Abdul Malik. Al-Risālah Al-Qusyairiyyah (Tahqīq Abdul Ḥalìm Mạ̣mūd Dan Mạ̣mūd Al-Syañf). Vol. 11. Cairo: Dār AlMa'ārif, 1989.

Al-Zain, Samīḥ 'āțif. Al-Ṣūfiyyah Fì Nạ̣ari Al-Islām Dirāsah Wa Taḥ̂lil. Beirut: Dār Al-Kitāb Al-Lubnānī, 1985.

Arberry, Arthur John. Sufism: An Account of the Mystics of Islam. England: Routledge, 1950.

Beck, Herman L. "The Contested State of Sufism in Islamic Modernism: The Case of the Muhammadiyah Movement in Twentieth-Century Indonesia." Journal of Sufi Studies 3, no. 2 (2014): 183-219. https://doi.org/10.1163/22105956-12341269.

Bellver, José. “"Al-Ghazālī of Al-Andalus': Ibn Barrajān, Mahdism, and the Emergence of Learned Sufism on the Iberian Peninsula." Journal of the American Oriental $\begin{array}{lllll}\text { Society } & 133, & \text { no. } & 4 & \text { 659-81. }\end{array}$ https://doi.org/10.7817/jameroriesoci.133.4.0659.

Ceyhan, Semih. "Ibn Khaldun's Perception of Sufis and Sufism: The Discipline of Tasawwuf in Umran." Asian Journal of Social Science 34, no. 3-4 (2008): 483515. https://doi.org/10.1163/156853108X327056.

Ernst, Carl W. Sufism: An Introduction to the Mystical Tradition of Islam. Berkeley: Shambhala, 2011.

Geoffroy, Eric. Introduction to Sufism: The Inner Path of Islam (Perennial Philosophy). Indiana: World Wisdom, 2010.

Green, Nile. Sufism: A Global History. United States: Wiley-Blackwell, 2012.

Hamka. Perkembangan \& Pemurnian Tasawwuf Dari Masa Nabi Muhammad Hingga Sufi-Sufi Besar. 2nd ed. Jakarta: Putra Abdi Bangsa, 2017.

Knysh, Alexander. Sufism: A New History of Islamic Mysticism. New Jersey: Princeton University Press, 2017.

Lewisohn, Leonard. Classical Persian Sufism from Its Origins to Rumi (700-1300). London: Oneworld Publications, 1999. 
The Heritage of Sufism: The Legacy of Medieval Persian Sufism (1150-1500). Vol. II. London: Oneworld Publications, 1999.

Maḥmūd, Abdul Ḥalīm. Qaḍiyyatu Al-Tașawwuf Al-Munqiż Min Al-Ḍalāl. Beirut: Dār al-Ma‘ārif, n.d.

Nasr, Seyyed Hossein. The Garden of Truth: The Vision and Promise of Sufism, Islam's Mystical Tradition. New York: HarperCollins, 2008.

Post, Arjan. "A Glimpse of Sufism from the Circle of Ibn Taymiyya." Journal of Sufi Studies 5, no. 2 (2016). https://doi.org/10.1163/22105956-12341289.

Qalaji, Muhammad Rawas, and Hamid Sadiq Quneibi. Mu'jamu Lughoti Al-Fuqoha'. 2nd ed. Beirut: Dar al-Nafaes, 1988.

Sedgwick, Mark. Western Sufism: From the Abbasids to the New Age. Oxford: Oxford University Press, 2016.

Stoddart, William, and R.W.J. Austin. Outline of Sufism: The Essentials of Islamic Spirituality (Perennial Philosophy). Indiana: World Wisdom, 2012.

Taimiyyah, Ahmad bin Abdul Halim Ibnu. Majmu' Al-Fatawa. Vol. 11. al-Madinah alNabawiyyah: Majma' al-Malik Fahd li Thiba'ati al-Mushaf Asy-Syarif, 1995. 